\title{
New data on some type-species \\ of Maastrichtian-Paleocene Dasycladales (Green algae) from Iran. Part I. Pseudocymopolia Eштот, 1970
}

\author{
Koorosh RASHIDI ${ }^{1}$ \\ Felix SCHLAgINTWEIT ${ }^{2}$
}

\begin{abstract}
Pseudocymopolia anadyomenea, the type-species of the genus, was described by ELLIOTT (1959) from the Maastrichtian of Iraq. Besides the type-locality, it was also recorded from the upper Maastrichtian Tarbur Formation of Iran, from Afghanistan and Tibet. A rich but moderately preserved material is analyzed herein, evidencing the presence of two discrete species: $P$. anadyomenea and $P$. acuta $\mathrm{n}$. sp. The new species is characterized by its thallus morphology displaying tapering, keeled segment margins. Besides the morphology, both are also distinguished by biometric parameters such as the outer diameter (D), inner diameter (d), and the d/D ratio. All other Lower Cretaceous species of Pseudocymopolia as well as the Maastrichtian $P$. anadyomenea have rounded segment margins. Both taxa from the Tarbur Formation occur in inner platform quiet water depositional settings whereas the Lower Cretaceous representatives typically characterize platform margin deposits.
\end{abstract}

\section{Key-words:}

- green algae;

- systematics;

- micropalaeontology;

- biostratigraphy;

- Upper Cretaceous;

- Paleocene

Citation: RAShidi K. \& SChlagintweit F. (2019).- New data on some type-species of Maastrichtian-Paleocene Dasycladales (Green algae) from Iran. Part I. Pseudocymopolia ElLIOTT, 1970.- Carnets Geol., Madrid, vol. 19, no. 6, p. 97-111.

Résumé : Nouvelles données sur quelques espèces-types de Dasycladales (algues vertes) du Maastrichtien-Paléocène d'Iran. $1^{\text {ère }}$ partie. Pseudocymopolia ELLIOTT, 1970.- Pseudocymopolia anadyomenea, l'espèce-type du genre, a été décrite par ELLIOTT (1959) à partir du Maastrichtien d'Irak. En dehors de la localité-type, elle a également été observée dans la Formation Tarbur du Maastrichtian supérieur d'Iran, en Afghanistan et au Tibet. Le matériel analysé, riche mais moyennement conservé, permet d'identifier deux espèces distinctes: $P$. anadyomenea et $P$. acuta $\mathrm{n}$. $\mathrm{sp}$. La nouvelle espèce se caractérise par la morphologie de ses thalles dont les bords des segments sont en pointes, carénés. Outre la morphologie, toutes deux se distinguent également par leurs paramètres biométriques parmi lesquels que le diamètre externe $(D)$, le diamètre interne $(d)$ et le rapport d/D. Toutes les autres espèces de Pseudocymopolia du Crétacé inférieur ainsi que $P$. anadyomenea de Maastrichtien ont des bords de segments arrondis. Les deux taxons de la Formation Tarbur se trouvent dans le contexte dépositionnel d'environnement calme caractéristique de la plateforme interne, alors qu'au Crétacé inférieur les représentants du genre caractérisent généralement les dépôts de bordure de la plate-forme.

\footnotetext{
1 Department of Geology, Yazd University, 89195-741 Yazd (Iran)

kooroshrashidi@yazd.ac.ir

2 Corresponding author

Lerchenauerstr. 167, 80935 Munich (Germany)

felix.schlagintweit@gmx.de
}

Published online in final form (pdf) on May 31, 2019

[Editor: Bruno GRANIER; language editor: Stephen EAGAR] 


\section{Mots-clefs :}

- algues vertes ;

- systématique ;

- micropaléontologie ;

- biostratigraphie ;

- Crétacé supérieur ;

- Paléocène

\section{Introduction}

Upper Maastrichtian and Paleocene shallowwater carbonates from Iran exhibit various assemblages of Dasycladales. Among them some type-species of taxa described from other areas are very abundant in certain levels. All of them are rather poorly recorded from their type-localities and only some additional findings have been recorded since then. Moreover they were established in times when descriptions of new taxa were delivered with only few illustrations and mostly limited analyses of dimensional data. Therefore, the Iranian findings add further knowledge on the overall morphology and the biometric ranges of these taxa. Each taxon will be described in a separate paper starting with the genus Pseudocymopolia ElLIOTT, 1970, from the late Maastrichtian Tarbur Formation of the Zagros Zone, SW Iran. Paleocene taxa will be discussed in forthcoming papers.

\section{The genus Pseudocymopolia Ештот, 1970}

In 1959, ELLIOT described a new species from the Maastrichtian of Iraq (Tanjero Formation) as Cymopolia anadyomenea. ElLIOTT noted the uniqueness of the new species within the genus Cymopolia Lamouroux expressed by the waxing and waning thallus morphology (or "flanges"), "a half-way stage between an ordinary single tubular dasyclad and the modern segmented Cymopolia" ElLIOTT, 1959, p. 218). A decade later ElLIOTT (1970) erected the new genus Pseudocymopolia with C. anadyomenea as type-species. Pseudocymopolia is known from the Tithonian?-Berriasian to Maastrichtian with $P$. anadyomenea representing the youngest species (BARATTOLO \& D'ANDREA, 1988; BUCUR, 1993; DRAGASTAN, 1999). The genus became extinct at the Cretaceous-Paleogene boundary (BARATTOLO, 2002). The comparison to Cymopolia made by ElLIOTT was also due to the assumed presence of fertile ampulla in the "flanges". ElliotT (1970, p. 324) and, therefore, it was considered taht Pseudocymopolia was "an aberrant early development of Cymopolia". BARATTOLO and D'ANDREA (1988) re-studied ELLIOTT's type material stored at the British Museum (Natural History, now known as Natural History Museum) in London stating that evidence for reproductive organs were not found. The same observations were made by BucuR (1993) on material of Pseudocymopolia jurassica (DRAGASTAN) from the Berriasian of Romania. Following Granier \& Deloffre (1993), P. jurassica Dra-
GASTAN, 1968, represents a nomen nudum (two specimens were designated as holotype). It was correctly typified by DRAGASTAN (1978), but too late thus becoming a junior synonym of $P$. pluricellata BAKALOVA, 1973. Due to the absence of sporangia, BUCUR (1993) emended the generic diagnosis and removed it from the Neomereae transferring it to the Triploporelleae. BUCUR (1993) showed that the thallus consists of superimposed or stacked ( $=$ interpenetrated) segments frequently occurring isolated. Generally the recrystallized calcareous envelope appears as compressed from its external appearance (BUCUR, 1993). Species of Pseudocymopolia are known from the Lower Cretaceous (Berriasian-Barremian, ? Aptian; BARATTOLO \& D'ANDREA, 1988; BuCUR, 1993; DRAGASTAN, 1999) and the Maastrichtian with a large gap of no records in between (e.g., Granier \& Deloffre, 1993; Barattolo, 2002). As valid species, the critical inventory of Granier \& Delofrre (1993) includes four species: P. anadyomenea (ELLIOTT, 1959), P. orientalis ELLIOTT, 1970, P. pluricellata BAKALOVA, 1973, and $P$. praturloni BARATTOLO \& D'ANDREA, 1988. Later, DRAGASTAN (1999) described a fifth species as $P$. transsylvanica.

In the original paper (ELLIOTT, 1959), P. anadyomenea was illustrated with 5 specimens in thin-sections that do not show all characteristics of this species. In his compendium on Permian to Paleocene algae from the Middle East, ELLiOTT (1968) additionally illustrated one solid specimen on weathered rock surface, and two new sections (also from the Maastrichtian of Iraq; Tanjero and Aqra formations). The specimen from the Aqra Formation (ELLIOTT, 1968: PI. 8, fig. 5) shows a different morphology of the segments displaying an irregular triangular outline in axial section with a tapering "keeled" margin. In describing $P$. orientalis from the Lower Cretaceous of Borneo, ELLIOTT (1970, p. 325) considered the keeled flanges present in $P$. anadomenea as one diagnostic feature. In the original description from 1959 however, this distinguishing feature was neither included nor illustrated. Both forms with rounded and keeled margins display discrete assemblages in the Tarbur Formation and are here described as two different species: $P$. anadyomenea (with rounded segment margins) and the new species $P$. acuta $\mathrm{n}$. sp. (with keeled margins). Both occur in the same inner platform environment excluding phenotypic adaptation of a single species (from higher to moderate energetic environments). Also none of the numerous longitudinal sections (with numerous segments) show both 


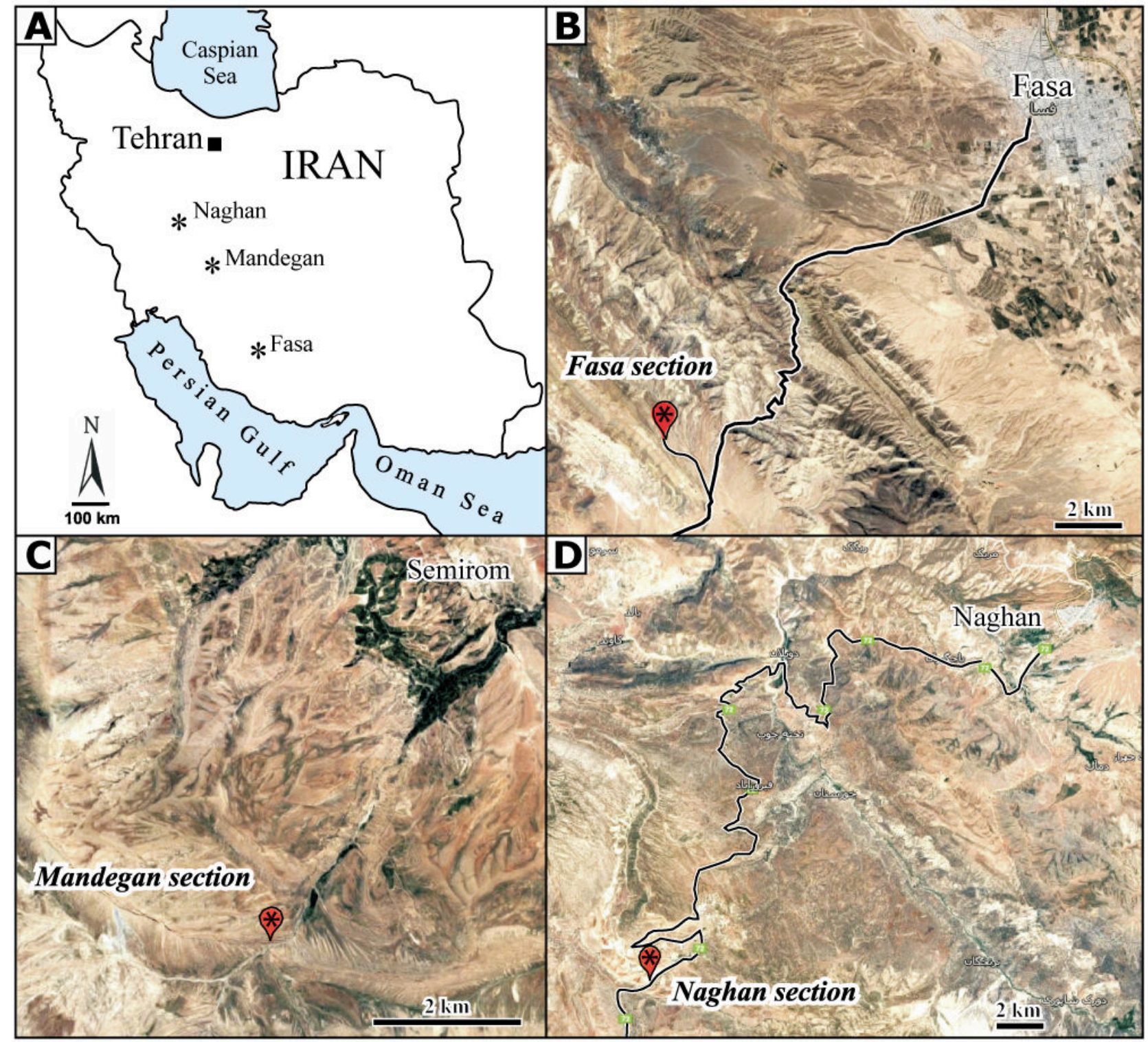

Figure 1: A: Location of the section of the late Maastrichtian Tarbur Formation with Pseudocymopolia anadyomenea (ELLIOTT), and Pseudocymopolia acuta n. sp. in Iran. B: Fasa section. C: Mandegan section. D: Naghan section. Satellite images (blured) from Google Maps.

morphologies, supporting the presence of two species. Last but not least, the two species are quite distinct in terms of biometric data. The poor state of preservation however hinders detailed study of the morphology of the laterals.

\section{Geological setting}

The Upper Cretaceous Tarbur Formation, named after the village of Tarbur (Fars Province), occurs in the SW Zagros basin. It is a predominantly carbonate lithostratigraphic unit containing a rich microfauna and microflora associated with rudists (JAMES \& WYND, 1965). Compared to the (larger) benthic foraminifera, the microflora however is less diversified. Outcrops of the Tarbur Formation extend from the northwest to the southeast of the Zagros basin along the western edge of the imbricated Zagros zone, between the main Zagros fault and the Sabzposhan fault to the east (ALAVI, 2004). The Tarbur Formation overlies and interfingers (towards the southwest) with the Gurpi Formation. The specimens of Pseudocymopolia recorded herein are from three sections of the Tarbur Formation: the Fasa, Naghan, and Mandegan sections (Fig. 1). Most of the illustrated specimens are from the first two localities.

\section{Fasa Section (Fig. 2.1-4)}

It is located in the interior Fars (Folded Zagros Belt), about $20 \mathrm{~km}$ southwest of Fasa, close to the Khane Nahar village. The exposed thickness of the Tarbur Formation is about $257 \mathrm{~m}$. At the base, it is covered by alluvium and the Gurpi Formation is not exposed (Fig. 2.1-2). The Tarbur Formation can be subdivided into 3 lithostratigra- 
phic units: unit $1(73.1 \mathrm{~m})$, consisting of medium- to thick-bedded limestones, followed by unit $2(124.4 \mathrm{~m})$, medium-bedded limestones with Loftusia (Fig. 2.3) and some intercalated dolomitic layers in the lower part, and finally unit 3 $(74.5 \mathrm{~m})$ medium- to thick-bedded limestones, yellow marls, and thick-bedded dolomites (uppermost part). Both Pseudocymopolia anadyomenea (ELLIOTT) and Pseudocymopolia acuta n. sp. occur in wackestone and floatstone microfacies. They are accompanied by larger benthic foraminifera and also rudists (PI. 1, fig. 3). Most samples are dominated either by one or by the other species, but they may also occur together. The top of the section is represented by the Paleocene Sachun Gypsum (Fig. 2.4). The coordinates of the section base are N2851'2.49", E5330'55.82".

\section{Naghan section (Fig. 2.5)}

It is located in the folded Zagros approximately $50 \mathrm{~km}$ south west of Naghan town near Gandomkar village. In this locality, the Tarbur Formation unconformably rests on the Gurpi Formation and is overlain by the Paleocene Sachun Formation. Lithologically, the Gurpi Formation consists of dark shales, grey calcareous shales containing planktonic foraminifera. The Sachun Formation consists of gypsum [see Fig. 2.5 (for the Fasa section)], red shales, anhydrite and some layer of carbonates. In the Tarbur Formation of the Naghan section the microfacies with Pseudocymopolia is equivalent to the one observed at the Fasa section (PI. 1, figs. 1-2, 4, 6). The thickness of the Tarbur Formation at the Naghan section is about $274 \mathrm{~m}$. The Greenwich coordinates of the section base are N3147'52", E50³2'53".

\section{Mandegan section}

The section is located in the High Zagros Belt, north of Mount Dena, and about $65 \mathrm{~km}$ south of Semirom city. It is exposed about $10 \mathrm{~km}$ south of the village of Mandegan (for further details of the location see ScHLAGINTWEIT et al. 2016a). There, the Tarbur Formation with a thickness of $\sim 272 \mathrm{~m}$ conformably overlies the Gurpi Formation. The top of the section is unconformably overlain by conglomerates of the Pliocene Bakhtiari Formation. Based on the lithostratigraphy, the section has been subdivided into three units (from base to top): unit 1 is dominated by thick-bedded limestones, unit 2 mostly contains medium-bedded limestones with intercalated marly limestone layers, and unit 3 consists of marly limestone. In the lower part of unit 1 characterized by an assemblage of siderolitids and orbitoidids; dasycladalean algae are lacking. In the upper parts reaching to the top, Dasycladales (including Pseudocymopolia species) are omnipresent. The Greenwich coordinates of the Mandegan section base are $\mathrm{N} 31^{\circ} 25^{\prime} 8.13^{\prime \prime}, \mathrm{E} 51^{\circ} 24^{\prime} 34.58^{\prime \prime}$.

\section{Material and depository}

All illustrated specimens are from thin-sections stored at the Ardakan Payame Noor University, Iran, in the RASHIDI collection, under the original sample numbers with the prefixes BT for the Fasa, NG and 2NG for the Naghan, and Rt for the Mandegan sections.

\section{Systematics}

\section{Phylum Chlorophyta \\ Class Dasycladophyceae}

Oder Dasycladales PASCHER, 1931

Family Triploporellaceae (PIA, 1920)

GRANIER \& BUCUR in GRANIER et al., 2012

Tribe Triploporelleae (PIA, 1920), BASSOULLET et al., 1979

\section{Subtribe Pseudocymopoliinae} BUCUR, 1993

\section{Genus Pseudocymopolia (ELLIOTT, 1970) BUCUR, 1993}

\section{Pseudocymopolia anadyomenea (ELLIOTT, 1959) ELLIOTT, 1970}

1959 Cymopolia anadyomenea n. sp. - ElLIOTT, PI. 1, figs. $1-4,8$

1968 Cymopolia anadyomenea (ELLIOTT) - ELLIOTT, PI. 7 , figs. $1-5$

1970 Pseudocymopolia anadyomenea (ELLIOTT) nov. comb. - ELLIOTT (not figured)

2016b Pseudocymopolia? sp. - SCHLAgINTWEIT et al. Fig. 8C

Description: The observed moniliform thallus fragments attain a maximum length of about 4.0 $\mathrm{mm}$. The largest specimen consists of four segments (PI. 2, fig. 2). Rarely the segments are barrel-shaped; usually the greatest width is attained in the upper third. The margins are always rounded. The upper side of the segments may be convex to almost plane. The inner surface may be smooth or only shows a slightly developed intusannulation. The laterals are bending upwards and attain their greatest width at the level of the greatest segment diameter (PI. 2, fig. 3). In transverse sections the numerous laterals are close-set and due to their bending only cut at the proximal part. At the outer margin of the same section, the laterals of one of the preceding whorls are cut (PI. 2, fig. 4). After the first third or the middle of their length, the primary laterals, tubular-cylindrical in shape, branch and give rise to secondaries (PI. 2, fig. 5). The number of secondaries to primary is unknown. Before reaching the outer margin, the secondaries are widening abruptly, presumably forming a cortex (PI. 2, fig. $3)$. In tangential sections, the close-set laterals display a polygonal outline (PI. 2, fig. 9). 

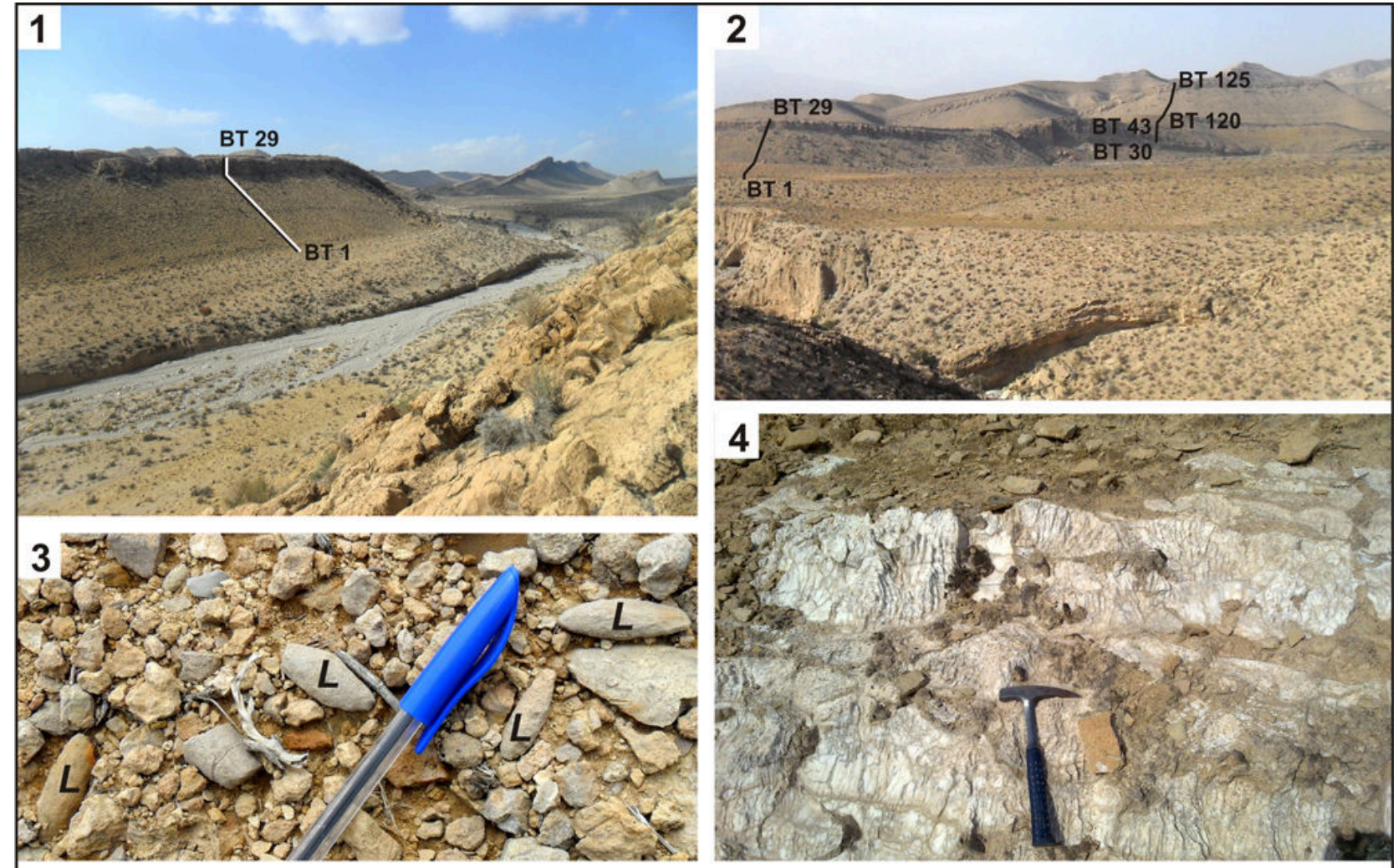

\section{SW}

NE

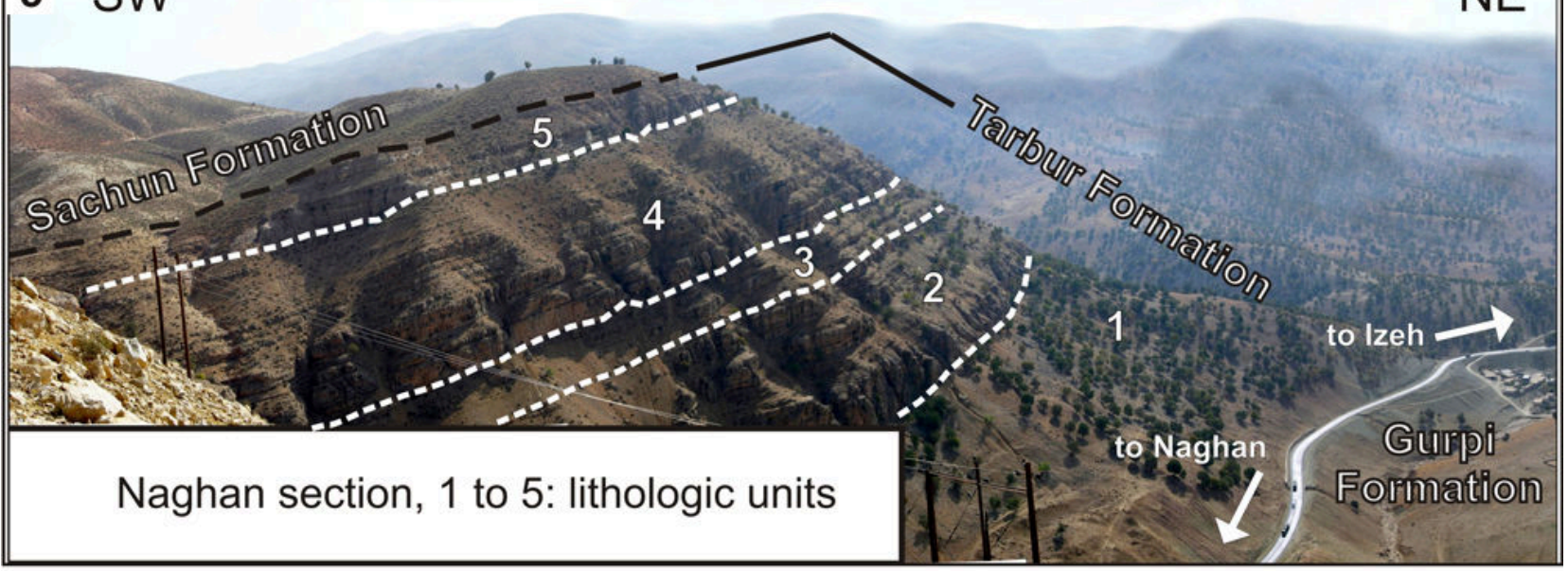

Figure 2: Field views of the Fasa (1-4) and Naghan sections (5). 1. View towards the south-west showing sample locations BT 1-29. View to the west showing sample locations BT 1-29, 30-43, and 120-125. 3. Weathered isolated specimens of the Larger Benthic Foraminifera Loftusia sp. (L). 4. Gypsum of the Paleocene Sachun Formation. 5. Naghan section. 
Dimensions: See Table 1 below.

Table 1: Biometric parameters (in $\mathrm{mm}$, except $\mathrm{d} / \mathrm{D}$ ) of Pseudocymopolia anadyomenea (ELLIOTT) from the Upper Maastrichtian Tarbur Formation of Iran. $\mathrm{D}=$ external diameter, $\mathrm{d}=$ internal diameter, $\mathrm{w}=$ number of sterile laterals per verticil, $\mathrm{H}=$ height of article.

\begin{tabular}{|c|c|c|c|c|c|c|}
\hline & sample & D & d & d/D & H & $\mathbf{w}$ \\
\hline 1 & NG 10 & 0.96 & 0.48 & 0.5 & 0.7 & - \\
\hline 2 & NG 53-3 & 2.8 & 1.58 & 0.56 & 1.2 & - \\
\hline 3 & NG 83-1 & 1.3 & 0.71 & 0.54 & 0.46 & - \\
\hline 4 & NG $83-2$ & 1.58 & 0.74 & 0.47 & 0.83 & - \\
\hline 5 & N 3 & 0.9 & 0.54 & 0.6 & 0.56 & - \\
\hline 6 & NG 84 & 1.2 & - & - & 0.59 & - \\
\hline 7 & NG 90 & 2.2 & 1.1 & 0.5 & 1 & - \\
\hline 8 & NG 116 & 1.37 & - & - & 0.97 & - \\
\hline 9 & NG 120 & 1.6 & 0.72 & 0.45 & 0.72 & - \\
\hline 10 & NG 120 & 1.37 & - & - & 0.84 & - \\
\hline 11 & NG 147 & 0.85 & 0.54 & 0.63 & 0.42 & - \\
\hline 12 & 2NG 34big & 0.84 & 0.47 & 0.56 & 0.52 & - \\
\hline 13 & 2NG 49 & 2.2 & 1.1 & 0.5 & 1.1 & - \\
\hline 14 & 2NG $81-3$ & 1.95 & 1.2 & 0.61 & - & 46 \\
\hline 15 & 2 NG $81-4$ & 1.44 & 0.66 & 0.46 & 0.97 & - \\
\hline 16 & 2 NG 93 & 1.56 & 0.9 & 0.58 & 0.75 & - \\
\hline 17 & 2NG 93 & 2.2 & 1.1 & 0.5 & 0.98 & - \\
\hline 18 & Rt 71 & 2.28 & 1.08 & 0.47 & 1.1 & - \\
\hline 19 & Rt $67-3$ & 1.2 & 0.76 & 0.63 & 0.62 & - \\
\hline 20 & Rt $67-3$ & 1.5 & - & - & 0.78 & - \\
\hline 21 & Rt 71 & 1.52 & 0.84 & 0.55 & 1.1 & - \\
\hline 22 & Rt $79-3$ & 2.04 & - & - & - & - \\
\hline 23 & Rt 79-3 & 1.68 & - & - & 1.34 & - \\
\hline 24 & Rt 83-2 & 1.32 & 0.65 & 0.49 & - & - \\
\hline 25 & Rt 86 & 0.9 & 0.52 & 0.58 & 0.4 & - \\
\hline 26 & Rt 86 & 1.5 & 0.8 & 0.54 & 0.84 & - \\
\hline 27 & Rt $89-3$ & 2.2 & 0.89 & 0.4 & 1.2 & - \\
\hline 28 & Rt 98-3 & 1.4 & 0.9 & 0.64 & 0.59 & - \\
\hline \multirow[t]{4}{*}{29} & Rt $98-3$ & 1 & 0.56 & 0.56 & 0.48 & - \\
\hline & range & $0.84-2.80$ & $0.48-1.58$ & $0.4-0.64$ & $0.42-1.20$ & 46 \\
\hline & mean & 1.52 & 0.84 & 0.53 & 0.78 & - \\
\hline & $\mathrm{n}$ & 29 & 23 & 23 & 26 & 1 \\
\hline
\end{tabular}

Remarks: Among the dimensional data we may note the relative great range of the segment height, accounting also for different morphologies. The maximum outer diameter is lower than the value indicated by ElLIOTT (1959), $3.6 \mathrm{~mm}$ vs. $2.6 \mathrm{~mm}$. As common values ELLIOTT indicated a range from 2.0 to $2.5 \mathrm{~mm}$. The number of laterals per verticil was indicated by ELLIOTT as 45-48. The only value we measured from the Tarbur Formation is 46 (PI. 2, fig. 4). In the upper part of the Tarbur Formation specimens of $P$. anadyomenea appear better preserved with light brownish calcification (PI. 2, figs. 3, 9). This might be due to the inclusion of organic material presumably replacing the original aragonitic composition (e.g., Granier, 2012) as observed also in other dasycladaleans from these levels (RASHIDI \& SCHLAGINTWEIT, 2018, for details). In these better preserved specimens, no traces of fertile ampullae were detected, confirming the observations already made by BARATTOLO \& D'ANDREA (1988) and BUCUR (1993). In his papers dated 1959 (original description) and 1968, ELLIOTT did not mention angular (or keeled) segment (or flange) morphologies. Only in his paper dated 1970 (creation of the genus Pseudocymopolia) ElLIOTT (op.cit., p. 325 ) noted that the margin swellings are keeled not rounded in $P$. anadymonea. As already mentioned in the introduction, we interpret these partly misleading statements as due to the simultaneous presence of two different species. The keeled forms are ascribed to $P$. acuta n.sp.

\section{Pseudocymopolia acuta n. sp.}

(PIs. 3-4)

1968 Pseudocymopolia anadyomenea (ELLIOTT) ELLIOTT, PI. 8, figs. 1, 5.

2016a Pseudocymopolia anadyomenea (ELLIOTT) SCHLAGINTWEIT et al., Fig. 9A-B

Origin of the name: The name refers to the acute segment margins.

Holotype: Longitudinal section illustrated in PI. 4, fig. 8, thin-section BT 8, Fasa section.

Diagnosis: Thallus large, moniliform, and of relatively constant diameter, consisting of segments displaying acute (or keeled) margins. The axial cavity is relatively large; intusannulation present. Laterals numerous, of first and second order. No reproductive structures observable.

Description: The observed moniliform fragments attain a maximum length of $\sim 6.7 \mathrm{~mm}$ consisting of seven segments. They are strongly recrystallized and preserved as sparry calcite often without any observable pores (PI. 3, fig. 4). The transition between two segments may be smooth (PI. 3, fig. 2, right specimen) or marked by an incision at the outer surface (PI. 3, fig. 1). No internal trace of discontinuity between contiguous segments was observed, likely due to the poor state of preservation and due to the quiet depositional setting, fragments of single segments are very rare. Most often fragments consisting of several segments prevail. The segments are tapering, distally forming an acute ("keeled") margin (e.g., PI. 3, fig. 3). The greatest diameter maybe symmetric in the middle part of the segment (e.g., PI. 4, fig. 7) or may be situated in the upper third of the segment (e.g., PI. 3, fig. 2). In these cases, the lower and upper outer segment surface is concave. Other morphologies include margins that are bending upwards with the lower side getting convex (PI. 3, fig. 5; PI. 4, fig. 2). Intusannulation is best developed in large-sized articles (PI. 3, figs. 1, 5-6). Segments of small diameter display a rather smooth inner surface, with very ill-developed to lacking intusannulation (PI. 4 , figs. 3, 8-9). Details of the laterals within each segments (dimensions, morphology) are commonly obscured due to strong recrystallization. Only rarely secondary laterals are visible (PI. 4, fig. 9). The secondaries are about $1 / 3$ of the 
length of the primaries. Their number per primary is unknown. The diameter of the observable numerous bended laterals only slightly widens throughout most of their length. Only at their distal ends they are widening markedly (PI. 4, fig. 4).

Dimensions: See Table 2. The inner diameter (d) is measured at the narrowing between two segments. In the swollen part, a pronounced intusannulation is present.

Table 2: Biometric parameters (in $\mathrm{mm}$, except $d / D$ ) of Pseudocymopolia acuta $\mathrm{n}$. $\mathrm{sp}$. from the Upper Maastrichtian Tarbur Formation of Iran. $D=$ external diameter, $\mathrm{d}=$ internal diameter, $\mathrm{w}=$ number of sterile laterals per verticil, $\mathrm{H}=$ Height of article.

\begin{tabular}{|c|c|c|c|c|c|}
\hline & sample & D & d & d/D & H \\
\hline 1 & BT 6 & 3.80 & - & - & 0.90 \\
\hline 2 & BT 6 & 2.55 & 0.90 & 0.35 & 1.00 \\
\hline 3 & BT 8 & 2.94 & 1.33 & 0.45 & - \\
\hline 4 & BT 8 & 3.26 & - & - & 1.37 \\
\hline 5 & BT 11 & 2.26 & 0.82 & 0.36 & 1.33 \\
\hline 6 & BT 15 & 1.56 & 0.57 & 0.36 & 0.52 \\
\hline 7 & BT 15 & 1.90 & 0.82 & 0.43 & 0.90 \\
\hline 8 & BT 15 & 2.53 & - & - & 1.80 \\
\hline 9 & BT 15 & 3.00 & 1.22 & 0.41 & 1.34 \\
\hline 10 & BT 15 & 2.55 & 1.14 & 0.45 & 1.29 \\
\hline 11 & BT 16 & 5.55 & - & - & 1.33 \\
\hline 12 & BT 16 & 2.65 & 0.90 & 0.34 & 1.00 \\
\hline 13 & BT 34 & 3.80 & - & - & - \\
\hline 14 & BT 34 & 4.39 & - & - & 1.33 \\
\hline 15 & BT 49 & 2.55 & - & - & 0.51 \\
\hline 16 & BT 121 & 3.14 & 1.00 & 0.32 & 1.12 \\
\hline 17 & BT 121 & 3.83 & - & - & - \\
\hline 18 & BT 121 & 2.75 & 1.08 & 0.39 & 1.32 \\
\hline 19 & 2NG 16 & 4.13 & - & - & 1.12 \\
\hline 20 & 2NG 16 & 4.15 & - & - & 1.60 \\
\hline 21 & $2 N G$ 34big & 2.88 & - & - & 0.98 \\
\hline 22 & 2 NG 34big & 4.45 & 1.44 & 0.32 & 1.34 \\
\hline 23 & 2 NG 34big & 2.28 & 0.96 & 0.42 & 1.20 \\
\hline 24 & 2 NG 34big & 3.45 & 1.08 & 0.31 & 1.37 \\
\hline 25 & 2 NG 34big & 5.40 & 1.68 & 0.31 & 1.56 \\
\hline 26 & NG 6 & 3.48 & - & - & 0.82 \\
\hline 27 & NG 6 & 2.20 & 0.72 & 0.33 & 0.84 \\
\hline 28 & NG 8 & 2.70 & - & - & - \\
\hline 29 & NG 14-1 & 2.64 & - & - & 1.25 \\
\hline 30 & NG 14-1 & 2.28 & - & - & 1.08 \\
\hline 31 & NG 34 & 5.04 & 1.33 & 0.26 & 1.04 \\
\hline 32 & NG 36 & 3.84 & - & - & 0.84 \\
\hline 33 & NG 49 & 2.4 & 0.72 & 0.30 & 0.48 \\
\hline 34 & NG 53-3 & 3.42 & - & - & 0.82 \\
\hline 35 & NG 60 & 2.65 & - & - & 0.82 \\
\hline 36 & NG 61 & 2.65 & 0.96 & 0.36 & 0.96 \\
\hline & range & $1.56-5.55$ & $0.57-1.68$ & $0.26-0.45$ & $0.48-1.8$ \\
\hline & mean & 3.07 & 1.04 & 0.36 & 1.01 \\
\hline & & & & & \\
\hline
\end{tabular}

Remarks: Concerning the dimensions, BARATTOLO and D'ANDREA (1988) noted that the species they described as $P$. praturlonii is the largest of all species. With a maximum diameter of $6.3 \mathrm{~mm}$ this holds true only for $P$. anadyomenea [ELLIOTT,
1959: $D \max =3.6 \mathrm{~mm}$ (2.8 $\mathrm{mm}$, this work)] while $P$. acuta is larger with Dmax of $5.5 \mathrm{~mm}$. The distinctive feature of $P$. acuta is the tapering, keel-forming segment margins, accompanied by a distinct intusannulation in larger segments. Sometimes, the distal portion of the segment margin is directed upwards. All other Lower Cretaceous species, $P$. pluricellata Bakalova, $P$. occidentalis ELLIOTT, and $P$. transylvanica DRAGASTAN have rounded segment margins. Moreover $P$. acuta is larger than the aforementioned taxa and displays a pronounced intusannulation. Apart from morphology, $P$. acuta differs from $P$. anadyomenea by its larger size (D), and a lower d/D ratio (see Tables 1-2). The observed largest thickness of the laterals at level of the greatest segment width is due to the slowly but continuous widening of the former throughout their length (see reconstruction in BARATTOLO \& D'ANDREA, 1988: Fig. 4). With respect to the biometric data, $P$. anydyomenea is clearly different from $P$. acuta n. sp. (see Tables 1-2). The outer diameter is distinctly larger in P. acuta n. sp., and also the $\mathrm{d} / \mathrm{D}$ ratio is different without any overlapping range (mean value 0.36 in $P$. acuta against 0.53 in $P$. anadyomenea). The intusannulation is much more pronounced in $P$. acuta than in $P$. anadyomenea.

\section{Concluding remarks}

In the late Maastrichtian Tarbur Formation of SW Iran, two different species of Pseudocymopolia ELLIOTT have been recognized: the type-species $P$. anadyomenea (ElLIOTT), and the new species $P$. acuta. The original description of ELLIOTT (1959) was essentially referring to $P$. anadyomenea with rounded segment margins. In his compendium from 1968 however ELLIOTT additionally illustrated a specimen with keeled segment margins that he also attributed to $P$. anadyomenea. Our investigations point to the presence of two separate species of Pseudocymopolia. These two species are the last representatives of the genus that became extinct at the Cretaceous-Paleogene boundary.

\section{Acknowledgments}

The constructive and helpful comments of the two reviewers Marc ConRad (Perly) and Ioan I. Bucur (Cluj-Napoca) are kindly acknowledged.

\section{Bibliographic references}

ALAVI M. (2004).- Regional stratigraphy of the Zagros foldthrust belt of Iran and its proforeland evolution.- American Journal of Science, Los Gatos, vol. 304, p. 1-20.

BAKALOVA D. (1973).- Calcareous algae from the Lower Cretaceous in northern Bulgaria.- Bulletin of the Geological Institute, Bulgarian Academy of Sciences - Committee of Geology (Series Paleontology), Sofia, vol. XX, p. 81-90. 
Barattolo F. (2002).- Late Cretaceous-Paleogene Dasycladaleans and the $\mathrm{K} / \mathrm{T}$ boundary problem. In: Bucur I.I. \& FIlipescu S. (eds.), Research advances in calcareous algae and microbial carbonates.- Proceedings 4th IFAA Regional Meeting, Cluj Napoca (29 August-5 September 2001), p. 17-40.

BARATtolo F. \& D'AndRea M. (1988).- Pseudocymopolia praturlonii n.sp. (Chlorophyta, Dasycladales) from Neocomian slope limestones of Colle della Croce (Marsica, Central Apennines).- Atti del Quarto Simposio di Ecologia e Paleoecologia delle Comunità Bentoniche, Sorrento 1-5 Novembre 1988, p. 123-149.

BuCUR I.I. (1993).- Remarks on Pseudocymopolia jurassica (DRAGASTAN, 1968).- Bollettino della Società paleontologica italiana, Modena, Speciale volume 1 , p. 69-80.

DRAGASTAN O. (1968).- Algues calcaires dans le Jurassique supérieur de Roumanie.- Geologica Romana, no. 7, p. 59-74.

DRAGASTAN O. (1978).- Microfacies de la série calcaire crétacé inférieure d'Aliman (Dobrogea de Sud).- Dări de seamă ale şedinţelor - Institutul de Geologie şi Geofizică, Bucuresti, vol. 64, no. 4 (1976-1977), p. 107-136.

DRAGASTAN O. (1999).- Jurassic-Cretaceous calcareous algae of the Transylvanides, Inner Dacides and Moesian Platform (Romania).- Revista Española de Micropaleontología, Madrid, vol. 31 , no. 2, p. 185-218.

ELLIOTT G.F. (1959).- New calcareous algae from the Cretaceous of Iraq.- Revue de Micropaléontologie, Paris, vol. 1, no. 4, p. 217-222.

ElliotT G.F. (1968).- Permian to Palaeocene calcareous algae (Dasycladaceae) of the Middle East.- Bulletin of the British Museum Natural History (Geology), London, Supple- ment 4, $111 \mathrm{p}$.

ElLIOTT G.F. (1970).- Pseudocymopolia, a Mesozoic Tethyan alga (Family Dasycladaceae).Palaeontology, London, vol. 13, no. 2, p. 323326.

Granier B. (2012).- The contribution of calcareous green algae to the production of limestones: a review.- In: BASSO D. \& GRANIER B. (eds.), Calcareous algae and the global change: from identification to quantification.- Geodiversitas, Paris, vol. 34, no. 1, p. 35-60.

GRANIER B. \& Deloffre R. (1993).- Inventaire critique des Algues Dasycladales fossiles. II $^{\circ}$ partie - Les Algues Dasycladales du Jurassique et du Crétacé.- Revue de Paléobiologie, Genève, vol. 12, no. 1, p. 19-65.

JAMES G.A. \& WYND J.G. (1965).- Stratigraphic nomenclature of Iranian Oil Consortium Agreement Area.- AAPG Bulletin, vol. 49, no. 12, p. 2218-2232.

RASHIDI K. \& SchlagintWeIt F. (2018).- Cymopolia eochoristosporica ELLIOTT, 1968 (green alga, Dasycladale) from the upper Maastrichtian of the Tarbur Formation (SW Iran).- Cretaceous Research, vol. 82, p. 99-103.

SCHLAGINTWEIT F., RASHIDI K. \& BARANi F. (2016a).First record of Gyroconulina columellifera SCHROEDER \& DARMOIAN, 1977 (larger benthic foraminifera) from the Maastrichtian Tarbur Formation of SW Iran (Zagros Fold-ThrustBelt).- GeoPersia, Tehran, vol. 6, no. 2, p. 169-185.

SCHLAGINTWEIT F., RASHIDI K. \& BabapidouR $M$. (2016b).- On the occurrence of Salpingoporella pasmanica RAdoIčić, 2002, (Dasycladales) from the Late Maastrichtian of the Zagros Zone, SW Iran.- Acta Palaeontologica Romaniae, Cluj-Napoca, vol. 12, no. 1, p. 33-42.

\section{Plates}

Plate 1: Microfacies (examples) of the Pseudocymopolia-bearing samples.

Upper Maastrichtian of the Naghan (1-2, 4, 6), Fasa (3), and Mandegan (5) sections, Zagros Zone, SW Iran.

Fig. 1: Wackestone to floatstone with Pseudocymopolia acuta n. sp. (left) and Pseudocymopolia anadyomenea (ELLIOTT) (right). Thin-section NG 14-1.

Fig. 2: Floatstone with Pseudocymopolia acuta n. sp. Thin-section NG 49.

Fig. 3: Oblique section of Pseudocymopolia acuta n. sp. (above) and larger benthic foraminifera Dicyclina schlumbergeri MUNIER-CHALMAS (below). Thin-section BT 8.

Fig. 4: Floatstone with tangential section (four segments) of Pseudocymopolia sp. (left below), and pieces of rudist shells. Note the random section of Pseudocymopolia acuta n. sp. right above. Thin-section NG 120.

Fig. 5: Floatstone with Pseudocymopolia anadyomenea (ELLIOTT) and small rudists. Note the light-brownish calcification pattern of the thallus. Thin-section Rt 71.

Fig. 6: Wackestone with Pseudocymopolia anadyomenea (ELLIOTT), other dasycladaleans, and larger benthic foraminifera, e.g., Persiella pseudolituus SchlaginTWEIT \& RASHIDI $(P)$. Thin-section 2NG 166. 


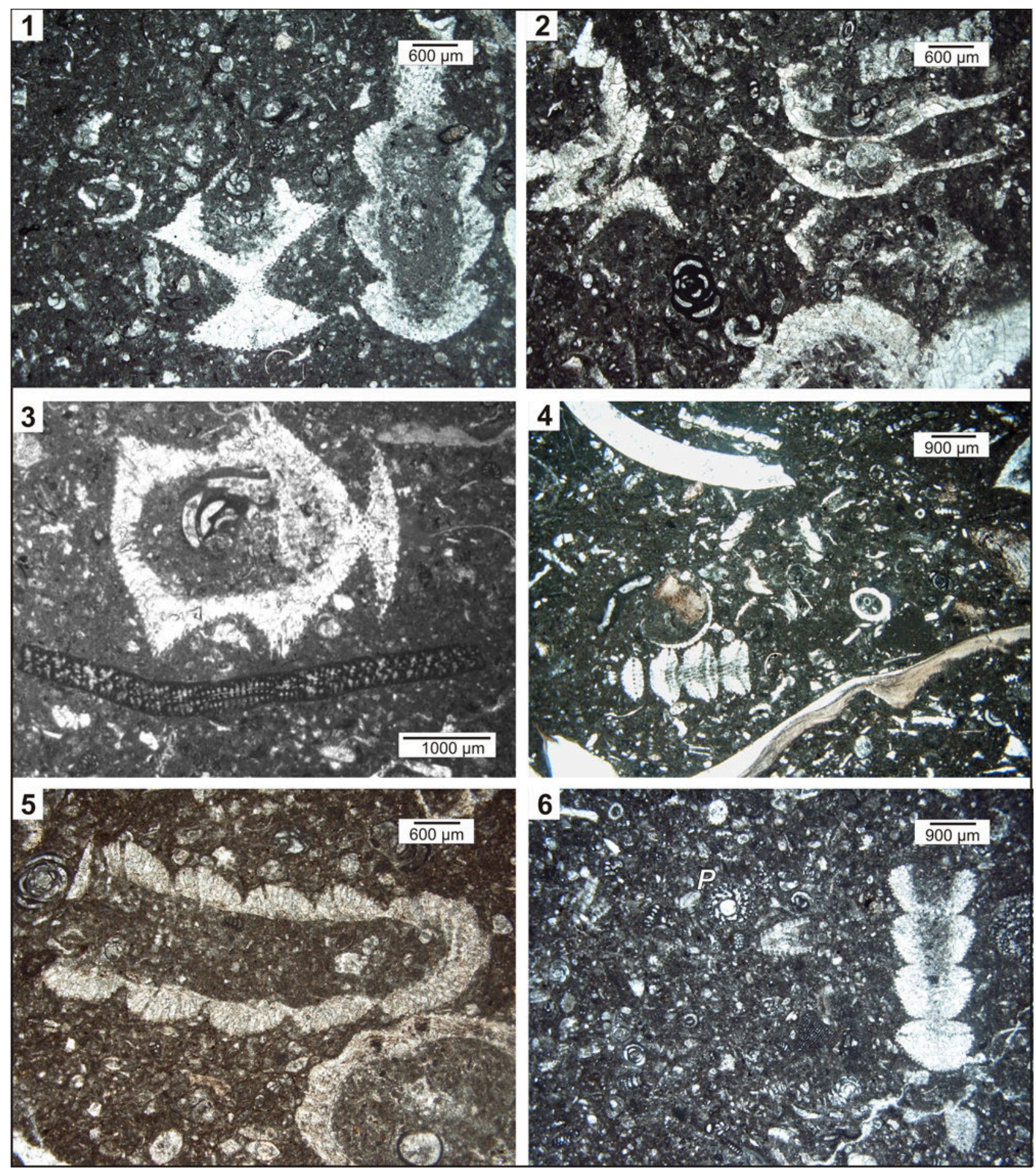


Plate 2: Pseudocymopolia anadyomenea (ELLIOTT)

Upper Maastrichtian of the Mandegan (6) and Naghan (1-5,7-10) sections, Zagros Zone, SW Iran. Scale bars $1 \mathrm{~mm}$. Fig. 1: Longitudinal-tangential section with five segments. Thin-section NG 84

Fig. 2: Longitudinal-tangential section passing through four segments. Thin-section NG 116.

Fig. 3: Oblique section through three segments. Note the light-brownish calcification pattern and the relatively thick and micrite-filled laterals in the upper third part of the segments (arrows). Thin-section 2NG 197.

Fig. 4: Slightly oblique transverse section. Thin-section 2NG 81-2.

Fig. 5: Detail of a segment showing the presence of second order laterals and the distal abrupt widening, presumably forming a cortex. Thin-section 2NG 11 .

Fig. 6: Slightly oblique longitudinal section of three segments. Thin-section Rt 67-1.

Fig. 7: Oblique-longitudinal section of five segments, Thin-section 2NG 93.

Fig. 8: Longitudinal section of two segments. Thin-section 2NG 81-4.

Fig. 9: Tangential section of one segment displaying brownish calcification. Note the layer of comparably thick micrite-filled laterals in the upper third of the segment. The close-set laterals display polygonal outlines in transverse section. Thin-section NG 197.

Fig. 10: Longitudinal section of 2 segments. Thin-section 2NG 87. 


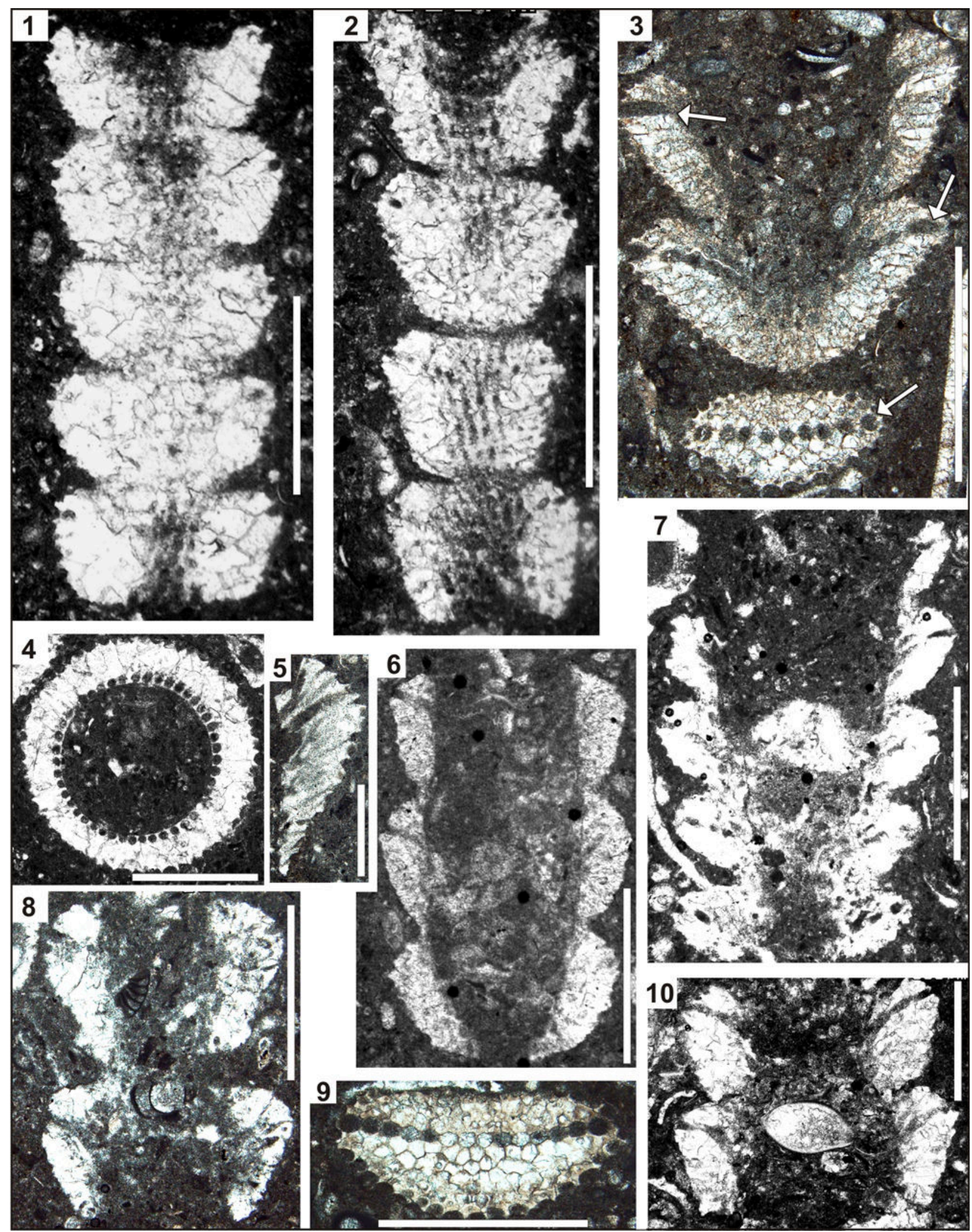


Plate 3: Pseudocymopolia acuta n. sp.

Upper Maastrichtian of the Mandegan (7) and Naghan (all others) sections, Zagros Zone, SW Iran. Scale bars $1 \mathrm{~mm}$.

Fig. 1: Longitudinal-oblique section of four segments. Note the intusannulation causing variable inner diameters. Transition between segments is marked by an incision at the outer surface (arrows). Thin-section 2 NG 16.

Fig. 2: Two specimens: longitudinal-oblique section (left) and longitudinal section (right). Note the relatively constant inner diameter. Thin-section 2NG 16.

Fig. 3: Longitudinal-oblique section cutting three visible segments. Thin-section 2NG 16.

Fig. 4: Tangential section cutting seven segments (the uppermost one randomly). Thin-section NG 14-1.

Fig. 5: Longitudinal-oblique section showing intusannulation. Thin-section 2NG 16.

Fig. 6: Longitudinal-oblique section. Note the extreme distal tapering of the segments forming keels. Thin-section NG 49.

Fig. 7: Oblique section of two segments. Note the light-brownish calcification. Thin-section Rt 82.

Fig. 8: Oblique section of a single segment. Thin-section NG 120. 


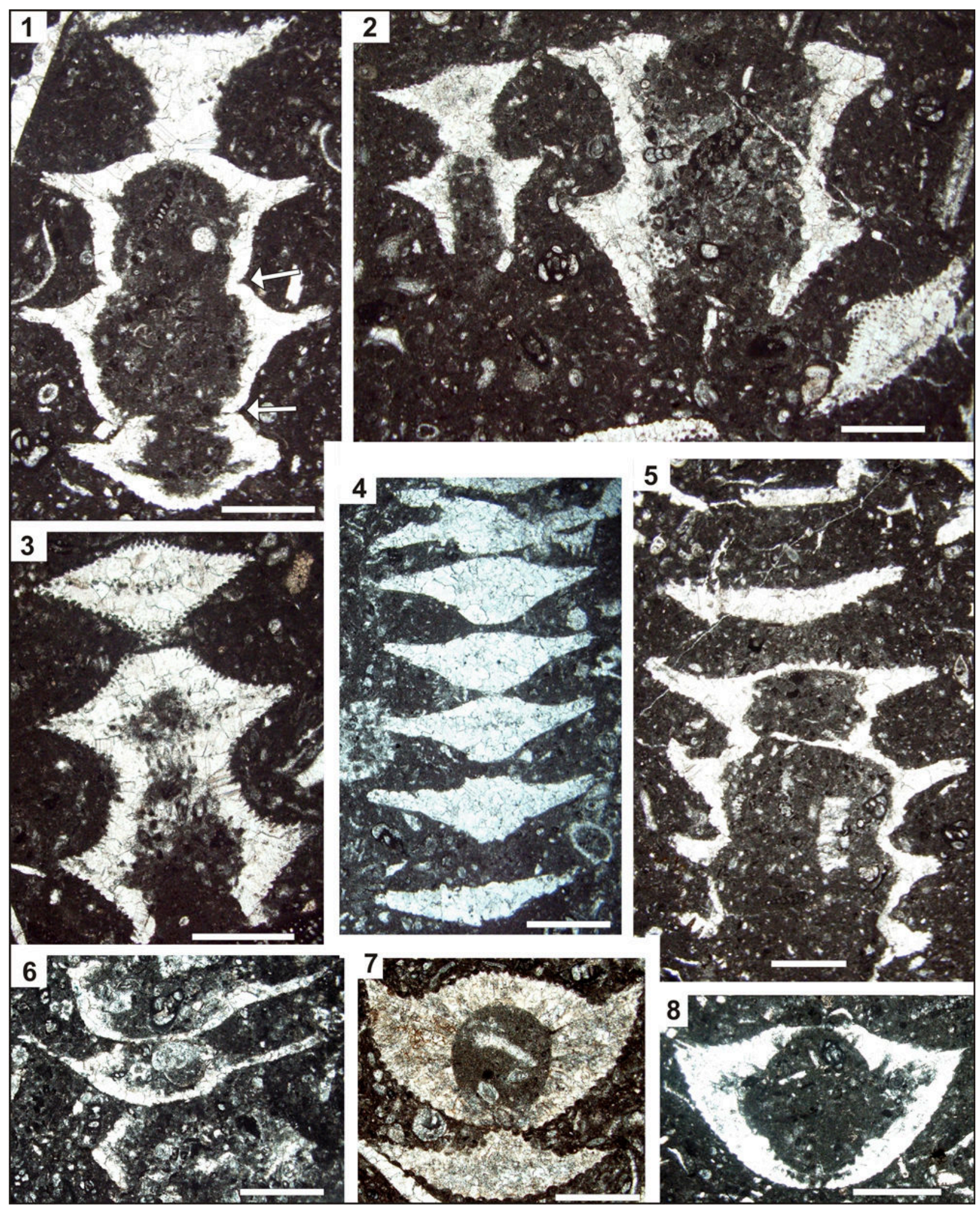


Plate 4: Pseudocymopolia acuta n. sp.

Upper Maastrichtian of the Naghan (1-2), Fasa (3-5, 7-9), and Mandegan (6) sections, Zagros Zone, SW Iran. Scale bars $1 \mathrm{~mm}$.

Fig. 1: Oblique longitudinal section of five segments. Thin-section NG 6.

Fig. 2: Oblique longitudinal section of four segments. Note the upward bending of the distal segment margin (arrows). Thin-section NG 14-1.

Fig. 3: Longitudinal section of six segments. Note the comparably low external diameter, but with well-developed keels (compare for example to Fig. 8). Thin-section BT 15.

Fig. 4: Slightly oblique-transverse section. Thin-section BT 16.

Fig. 5: Tangential-oblique section of two segments. Thin-section BT 6.

Fig. 6: Tangential section of an isolated segment. Thin-section Rt 67-3.

Fig. 7: Longitudinal section of three segments. Note the intusannulation is weak. Thin-section BT 121.

Fig. 8: Longitudinal section of three segments; holotype specimen. Thin-section BT 11.

Fig. 9: Detail from Figure 8 showing secondary laterals.

Fig. 10: Longitudinal section of three segments (right above) and one oblique section (left, below). Thin-section BT 16. 


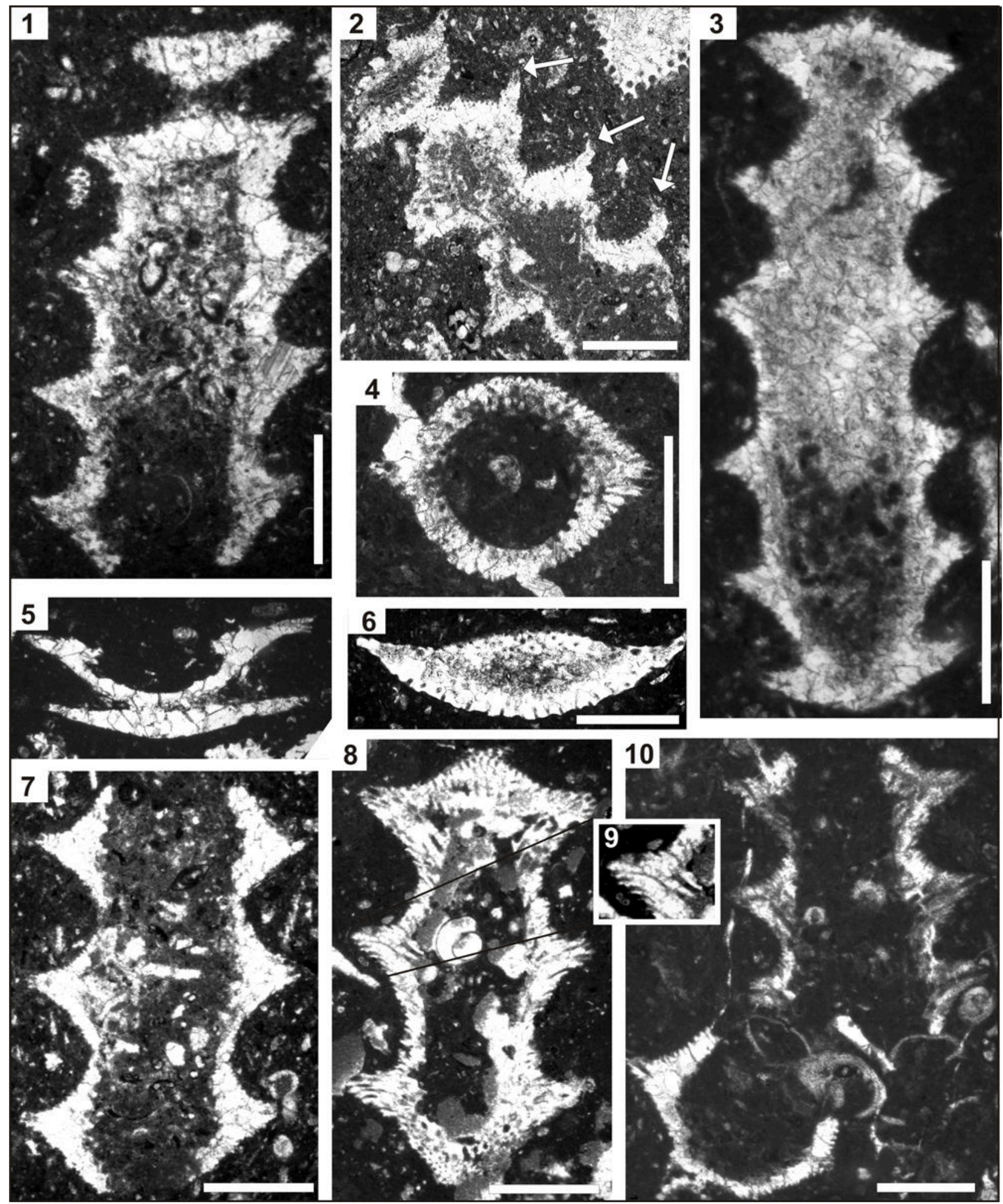

